Mager, J., Kuczynski, M., Schatzberg, G. \& Avi-Dor, Y. (1956). J. gen. Microbiol. 14, 69-75

\title{
Turbidity Changes in Bacterial Suspensions in relation to Osmotic Pressure
}

\author{
BY J. MAGER,* MIRIAM KUCZYNSKI, GISELA SCHATZBERG \\ AND Y. AVI-DOR \\ Israeli Institute for Biological Research, Ness-Ziona, Israel
}

SUMMARY: The turbidity of suspensions of various Gram-negative bacteria is affected by the tonicity of the suspending medium. The light extinction of the suspension increases in a nearly exponential fashion with the solute concentration and approaches a maximum at concentrations close to $0 \cdot 15 \mathrm{M}-\mathrm{NaCl}$. The maximal optical response to tonicity changes varies widely in different bacterial species, ranging from 30 to $140 \%$ increase in light extinction as compared with the turbidity of the suspension in distilled water. The turbidity changes seem to depend on the viability of the bacterial cells as they cannot be elicited in bacteria killed by various procedures. The influence of the described phenomenon on the determination of bacterial cell concentration by the customary turbidimetric methods is discussed and its application for the estimation of the number of viable cells is suggested.

In the course of a study of the effect of osmotic pressure on the respiration of certain micro-organisms, it was observed that the turbidity of bacterial suspensions changed with variations of the osmotic pressure of the suspending medium. Since to our knowledge such a phenomenon has not been described in bacteria before, an investigation into the factors governing these turbidity changes was undertaken.

\section{ME'THODS}

Culture media. The micro-organisms with the exceptions indicated below were grown on nutrient agar (Difco) slopes. For cultivation of Corynebacterium xerosis the nutrient agar was fortified with $1 \%(\mathrm{w} / \mathrm{v})$ maltose and $5 \%(\mathrm{v} / \mathrm{v})$ neutralized tomato juice. Five $\%(\mathrm{w} / \mathrm{v}) \mathrm{NaCl}$ was included in the medium for the growth of halophilic organisms and it was supplemented with $0 \cdot 1 \%$ Tween 40 for Mycobacterium phlei. Pasteurella pestis was cultivated on brain heart infusion agar (Difco), $P$. tularensis on a $3 \%(\mathrm{w} / \mathrm{v})$ peptone (Difco) cysteine medium (Mager, Traub \& Grossowicz, 1954), and Clostridium botulinum in a casein hydrolysate partially defined medium as described by Mager, Kindler \& Grossowicz (1954).

Inoculum. For inoculation usually $0.1 \mathrm{ml}$. of a $24 \mathrm{hr}$. culture suspended in $5.0 \mathrm{ml}$. saline was used. Unless otherwise stated, the cultures were incubated at $37^{\circ}$.

Chemicals. All chemicals used were of reagent grade. The different biological preparations were purchased from commercial sources.

* Present address : Department of Biochemistry, The Hebrew University, Hadassah Medical School, Jerusalem. 
Procedure for measuring the optical effect. The bacterial cells were washed twice with distilled water and the final aqueous suspension was adjusted to an optical density $\left(E_{w}\right)$ of 0.20 as measured at $500 \mathrm{~m} \mu$. in the Coleman Junior spectrophotometer. The solute in the required concentration was added in $\mathbf{0 . 3} \mathrm{ml}$. volume to $3.0 \mathrm{ml}$. of the above suspension and the resulting extinction $\left(E_{s}\right)$ was read after $1 \mathrm{~min}$. and corrected for the dilution. In some experiments the Beckman spectrophotometer model D.U. was used (Corex cells, $1 \mathrm{~cm}$. light path).

\section{RESULTS}

With increasing amounts of electrolytes or non-electrolytes added to suspensions of bacteria in distilled water, the light extinction increased gradually. The effect increased up to concentrations close to the range of isotonicity of these substances (Fig. 1). For a given solute concentration the percentage increase of light extinction, referred to the turbidity of the suspension in water, remained constant over a wide range of dilutions (from $E_{500}=0 \cdot 700$ to $E_{500}=0 \cdot 030$ in the Beckman spectrophotometer) and was independent of the wavelength used.

\section{Survey of micro-organisms}

Representatives of the different species of bacteria were assayed with $\mathrm{NaCl}$ or glucose for turbidity changes, as described under Methods. A scrutiny of the results, assembled in Table 1, shows that all the Gram-negative organisms examined exhibited the optical effect (o.E.) when tested with $\mathrm{NaCl}$ and most of them also in the glucose test; no appreciable o.E. could be demonstrated with any of the Gram-positive bacteria tested.

The magnitude of the effect $\left(E^{\prime}\right)$ in percentage $\left(E^{\prime}=\frac{E_{s}-E_{w}}{E_{w}} \times 100\right.$, where $\boldsymbol{E}_{w}$ is the light extinction of the suspension exhibited in water, and $\boldsymbol{E}_{s}$ the extinction in the solute) varied with different Gram-negative organisms from 30 to 140 . The high effect ( $E^{\prime}$ from 100 to 140 ) exhibited by the different strains of Pasteurella tularensis made it especially suitable for quantitative studies of the phenomenon. In most experiments the avirulent strain S \& D was used.

\section{Solutes which produced optical effect (o.E.)}

The osmotic nature of the o.E. was indicated by the finding that different substances, both electrolyes and non-electrolytes, elicited turbidity changes. Some solutes, such as urea, ethylurethane and glycols, which are known to be highly diffusible through biological membranes (Colländer, 1937; Danielli, 1952) and high molecular substances (inulin, plasma albumin) were ineffective (Table 2). As can be seen from Fig. 1, the mono-monovalent electrolytes tested exhibited, in equimolar concentrations, equal optical effects. With other solutes, however, the magnitude of o.E. $\left(E^{\prime}\right)$ as compared with $\mathrm{NaCl}$ of equal molar strength, varied with the concentration. For $0.033 \mathrm{M}$ solutions the values obtained for the ratio $E^{\prime}$ solution $/ E^{\prime} \mathrm{NaCl}$ were: $\mathrm{Na}_{2} \mathrm{SO}_{4}, 1 \cdot 44$; $\mathrm{MgCl}_{2}, 1 \cdot 80$; glucose, $0 \cdot 46$; for higher concentration it approached unity, i.e. for 0.132M: $\mathrm{Na}_{2} \mathrm{SO}_{4}, 1 \cdot 03 ; \mathrm{MgCl}_{2}, 1 \cdot 33$; glucose, 0.99. 
Table 1. Test for optical effect in different micro-organisms

Age of culture: $18 \mathrm{hr}$. Conditions of growth as indicated in Methods. The o.E. of the halophilic micro-organisms Micrococcus halodenitrificans and Vibrio costiculus represents the difference in light extinction exhibited in $1 \%(\mathrm{w} / \mathrm{v})$ and $7 \%(\mathrm{w} / \mathrm{v}) \mathrm{NaCl}$ solutions respectively.

\section{Optical \\ effect in \\ $\mathrm{NaCl}$ Glucose}

(1) Escherichia coli strain 6

(2) E. coli strain B

(3) E. coli strain $\mathrm{B} / \mathrm{r}$

(4) Aerobacter aerogenes

(5) Proteus vulgaris

(6) Alcaligenes faecalis

(7) Salmonella schottmuelleri

(8) S. hirschfeldii

(9) S. paratyphi

(10) S. typhosa

(11) Shigella ambigua

(12) S. sonnei

(13) Micrococcus lysodeikticus

(14) Staphylococcus aureus

(15) Staphylococcus albus

(16) Streptococcus faecalis

(17) Neisseria perflava

(18) N. catarrhalis

(19) Pasteurella pestis, 1122

++
++
++
+
+
++
++
++
++
++
++
++
-
-
-
-
+
++
++

$+$ $+$ $++$ nt nt $++$ nt $+$ $+$ nt $+$ $+$ $-$
(20) P. pestis, strain $\mathrm{H}_{2}$

(21) $P$. tularensis, strain Vir

(22) P. tularensis, strain 176

(23) P. multocida

(24) P. pseudotuberculosis

(25) Brucella suis

(26) B. abortus

(27) B. melitensis

(28) Malleomyces mallei

(29) Corynebacterium xerosis

(30) Lactobacillus arabinosus

(31) Mycobacterium phlei

(32) Bacillus subtilis

(33) B. anthracis

(34) Clostridium parabotulinum

(35) Vibrio cholerae, 35

(36) $V$. paracholerae (El-Tor)

$*(37) \dagger$ Micrococcus halodenitrificans

*(38) V. costiculus
Optical effect in $\overbrace{\text { NaCl Glucose }}$

$\begin{array}{cc}+ & + \\ ++ & \text { nt }\end{array}$

+++ nt

$++\mathrm{nt}$

$++\mathrm{nt}$

$++t$

$++\mathrm{nt}$

++ nt

$++\mathrm{nt}$

- -

- nt

nt -

- -

- nt

- nt

$++++$

++ nt

$++n t$

$++n t$

- denotes turbidity changes less than $5 \%$; denotes turbidity changes from 5 to $50 \%$; ++ denotes turbidity changes from 50 to $100 \% ;+++$ denotes turbidity changes over $100 \% ;$ nt = not tested.

* Halophilic species kindly supplied by Dr W. L. Flannery, University of Maryland.

$\dagger$ This strain was Gram-negative by the staining procedure used (Burke, 1922).

\section{Table 2. Effect of various solutes on optical effect}

Solutes, unless otherwise indicated, were used in $0.5 \mathrm{~m}$ concentration. The test organisms were: Escherichia coli (strains 6 and $5 ; 18 \mathrm{hr}$.) and Pasteurella tularensis (strain S \& D; 24 hr.).

Solutes which produced the optical effect

Sodium chloride

Ammonium chloride

Calcium chloride

Magnesium chloride

'Tris' chloride

Histidine chloride

Sodium sulphate

Ammonium sulphate

Manganous sulphate

Sodium nitrate

Ammonium nitrate

Sodium formate

Ammonium formate

Sodium acetate

'Tris'-acetate

Histidine acetate

Sodium citrate
Ammonium phthalate

Glycine

Glucose

Galactose

Mannose

Sucrose

Inositol

Sorbitol

Mannitol
Solutes which did not produce the optical effect

Urea

Ammonium formate

Ammonium acetate

Glycerol

Ethylene glycol

Propylene glycol

Inulin $2 \%(\mathrm{w} / \mathrm{v})$

Bovine plasma albumin $1 \%(w / v)$ 


\section{Influence of phase of growth and $\mathrm{pH}$ value}

Under otherwise identical conditions the o.E. was found to be maximal with cells harvested at the end of the lag phase. The o.E. decreased during the logarithmic stage of growth and attained a constant level in the stationary phase (Fig. 2).

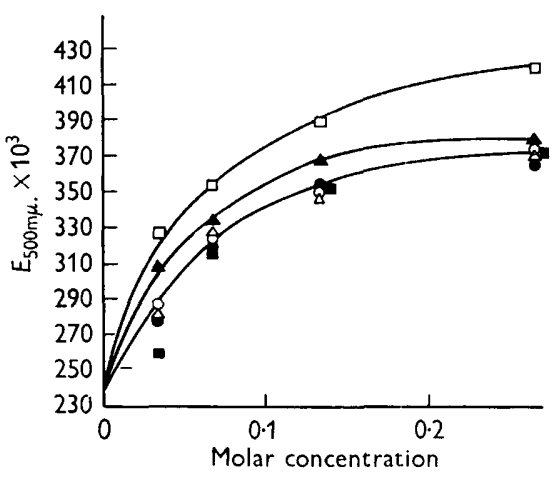

Fig. 1

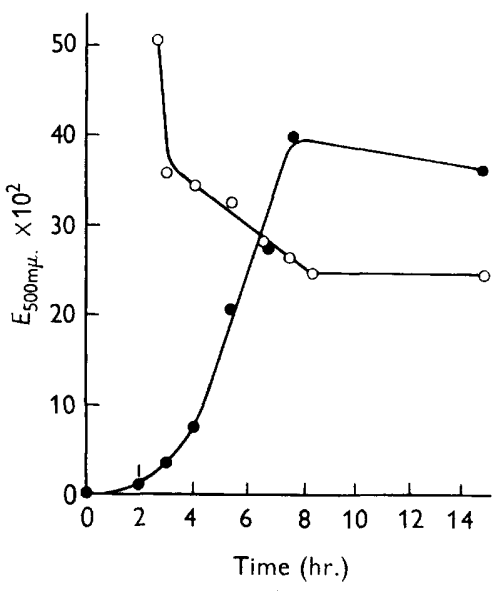

Fig. 2

Fig. 1. Changes in the light extinction of suspensions of Pasteurella tularensis with variation in the osmotic pressure of the suspending medium. Each Beckman cell contained the solutes in the concentrations indicated. Total volume $\mathbf{3 . 0} \mathrm{ml}$. Aqueous suspension of $P$. tularensis (strain $\mathbf{S} \& \mathbf{D}$ ) was added and the turbidity changes followed with the time. The maximal values of the extinctions were recorded. $\mathrm{O}-\mathrm{O}, \mathrm{NaCl}$;

$\mathrm{KCl} ; \triangle-\triangle, \mathrm{NaNO}_{3} ; \Delta-\Delta, \mathrm{Na}_{2} \mathrm{SO}_{4} ; \square-\square, \mathrm{MgCl}_{2} ; \mathbf{\square}-\mathbf{\square}$, Glucose.

Fig. 2. Phase of growth and optical effect: $O-O$, percentage increase in light extinction $\left(E^{\prime}\right)$ on addition of $\mathrm{NaCl}$ (final concentration $0.5 \mathrm{M}$ ) to an aqueous suspension of Escherichia coli; - - , growth curve of $E$. coli in nutrient broth. Optical effect was determined on samples taken at the times indicated.

In the different strains of Pasteurella tularensis tested, the period of incubation could be extended for several days (10-14) without any decrease in the o.E. being noticed. With other organisms, however, prolonged incubation resulted in a progressive diminution of the optical response of the bacteria to changes in osmotic pressure. As the medium used for the cultivation of $P$. tularensis contained unusually large amounts of buffer (Mager, Traub \& Grossowicz, 1954), it was thought that the stability of the $\mathrm{pH}$ value in these cultures might account for the exceptional behaviour of this micro-organism. In fact, when the composition of the culture media used for other microorganisms was modified in such a manner as to prevent large variations of $\mathrm{pH}$ value during growth, the decrease in the o.E. was considerably delayed ('Table 3).

When washed cells were incubated in buffer solutions of different $\mathrm{pH}$ values the o.E. proved to be most persistent between $\mathrm{pH} 6$ and 7 (Fig. 3). The similarity between the curve of Fig. 3 and the plate counts (cf. Winslow \& 
Falk, 1923) suggested that the o.E. depends on the viability of the organisms. This assumption was strengthened by the observation, that certain injurious treatments such as heating (Fig. 4) or alternate freezing and thawing (Table 4) reduced both the viability of the bacteria and the o.E. in nearly the same

Table 3. Influence of variations of $\mathrm{pH}$ value in the culture medium on viable count and optical effect

At the time of inoculation, the $\mathrm{pH}$ value of culture media was $6 \cdot 8$ in the two media tested.

\begin{tabular}{|c|c|c|c|c|}
\hline \multirow[b]{2}{*}{ Age of culture (hr.) } & \multicolumn{2}{|c|}{$\begin{array}{c}\text { Phosphate buffer } 1 \%(w / v \\
\text { Glucose } 0 \%(w / v)\end{array}$} & \multicolumn{2}{|c|}{ Glucose $2 \%(\mathrm{w} / \mathrm{v})$} \\
\hline & 18 & 120 & 18 & 120 \\
\hline Viable count (organisms $/ \mathrm{ml}$.) & $2.6 \times 10^{8}$ & $2.2 \times 10^{8}$ & $8 \cdot 5 \times 10^{7}$ & $8 \times 10^{6}$ \\
\hline$E^{\prime}$ value* & 50 & 50 & 80 & 10 \\
\hline $\mathrm{pH}$ value & $7 \cdot 3$ & $7 \cdot 4$ & $4 \cdot 8$ & $4 \cdot 5$ \\
\hline
\end{tabular}

* $E^{\prime}$, percentage increase in light extinction (see page 70 ).

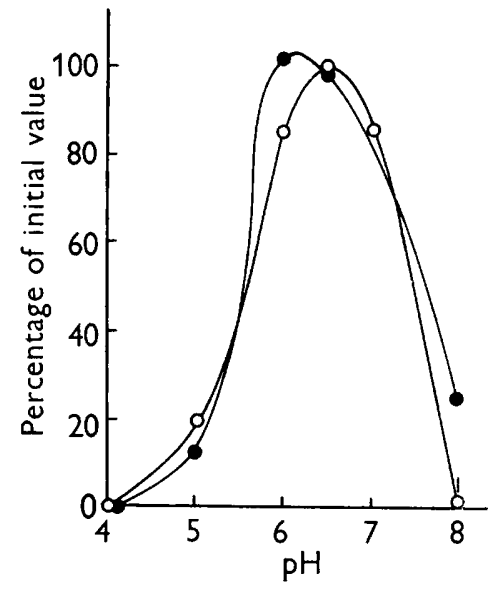

Fig. 3

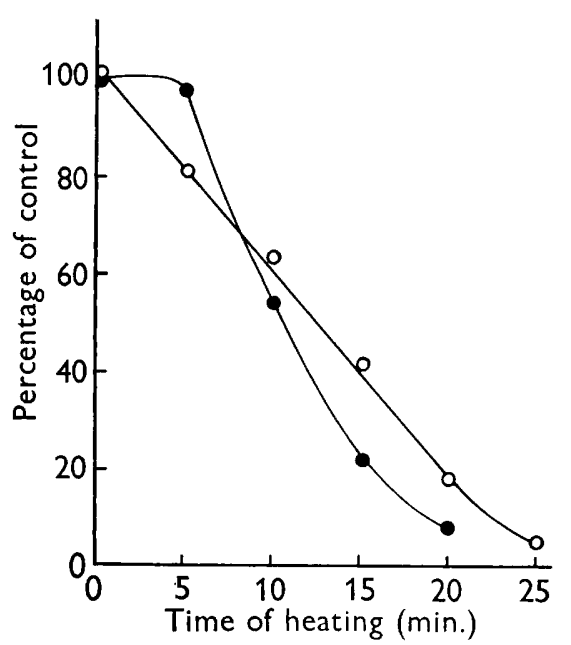

Fig. 4

Fig. 3. Effect of $\mathrm{pH}$ value on the viability and optical effect. Escherichia coli (strain $5 ; 20 \mathrm{hr}$.) was incubated with McIlvaine buffer $(0 \cdot 1 \mathrm{M})$ at various $\mathrm{pH}$ at $37^{\circ}$. After $17 \mathrm{hr}$. bacteria were washed and optical effect measured. $\bigcirc-0$, optical effect; -0 , viable count.

Fig. 4. Decrease in optical effect $\bigcirc-\bigcirc$, and in viable count $\longrightarrow$, after various times of heating. Samples of a suspension of Escherichia coli (strain 6) were heated in a water bath at $65^{\circ}$.

proportional manner. It may be noted, however, that suspensions treated by freezing and thawing exhibited negative optical effects, i.e. their extinction was higher in water than in $\mathrm{NaCl}$ solution. Moreover, bactericidal agents, in their effective concentrations, invariably abolished the o.E., while bacteriostatic substances such as antibiotics or competitive growth inhibitors (sulphadiazine) were without effect (Table 5). 


\section{$74 \quad$ J. Mager, M. Kuczynski, G. Schatzberg and Y. Avi-Dor}

Table 4. Effect of alternate freezing and tharving on viable count and optical effect

Suspension of Escherichia coli (strain 6); $E_{500}=0 \cdot 20.18 \mathrm{hr}$. culture suspended in gelatine $0.2 \%(\mathrm{w} / \mathrm{v})$, phosphate buffer $0.5 \%(\mathrm{w} / \mathrm{v})$ at $\mathrm{pH} 7$ was frozen by immersion into ethanol + solid $\mathrm{CO}_{2}$ mixture. After the mass solidified it was dipped into a $\mathbf{2 5}^{\circ}$ bath. The procedure was repeated ten times. After each treatment samples were removed, washed, resuspended in distilled water and the o.E. measured.

\begin{tabular}{|c|c|c|c|c|}
\hline \multirow{2}{*}{$\begin{array}{l}\text { Number of } \\
\text { treatments }\end{array}$} & \multirow{2}{*}{$\begin{array}{c}E^{\prime} \\
\text { value }\end{array}$} & \multicolumn{2}{|c|}{$\begin{array}{l}\text { Viable cells } \\
\text { from plate counts }\end{array}$} & \multirow{2}{*}{$\begin{array}{c}\text { Viable cells } \\
\text { calculated } \\
\text { from } E^{\prime *} \\
(\%)\end{array}$} \\
\hline & & $\left(\times 10^{7}\right)$ & $(\%)$ & \\
\hline 0 & 55 & 110 & 100 & 100 \\
\hline 2 & 40 & 89 & 84 & 81 \\
\hline 4 & 28 & 65 & 61 & 65 \\
\hline 6 & -7 & 22 & 23 & 21 \\
\hline 10 & -23 & $\mathbf{1}$ & 1 & 0 \\
\hline
\end{tabular}

* The values in this column were calculated from the equation

$$
\% \text { of viable cells (after } n \text { treatments) }=\frac{E_{n}^{\prime}-E_{10}^{\prime}}{E_{0}^{\prime}-E_{10}^{\prime}} \times 100,
$$

$E_{0}^{\prime}$ and $E_{10}^{\prime}$ represent the o.E. before and after 10 treatments respectively, $E_{n}^{\prime}$ after $n$ treatments.

\section{Table 5. Inhibition of the optical effect by different substances}

Organism: Escherichia coli; $16 \mathrm{hr}$. culture. Inhibitors in molar concentration unless otherwise stated.

Cupric chloride

Mercuric chloride

Potassium cyanide

Potassium ferricyanide

Silver nitrate

Sodium azide

Sodium meta-arsenite

Phenyl mercuric nitrate

Sodium iodoacetate

Thiomersalate

$p$-Chloromercuribenzoate

Chloramine $\mathbf{T}$

Cetylpyridinium bromide

Duponol

Penicillin G sodium salt

Sodium sulphadiazine

Dihydrostreptomycin

Phenol

2:4-Dichlorophenol

Formol

Hydrogen peroxide

8-Hydroxyquinoline

8-Hydroxyquinoline + ferrous sulphate

$50 \mathrm{mg} . / \mathrm{ml}$.
Degree of inhibition of o.k. $(\%)$

\begin{tabular}{|c|c|c|}
\hline 100 & $\begin{array}{c}50 \\
\text { concentration (M) }\end{array}$ & 0 \\
\hline $1 \times 10^{-4}$ & $2 \times 10^{-6}$ & - \\
\hline $2.5 \times 10^{-6}$ & $5 \times 10^{-7}$ & . \\
\hline - & - & $5 \times 10^{-2}$ \\
\hline . & . & $1 \times 10^{-2}$ \\
\hline $1 \times 10^{-4}$ & $1 \times 10^{-5}$ & . \\
\hline · & . & $1 \times 10^{-1}$ \\
\hline . & . & $1 \times 10^{-2}$ \\
\hline $1 \times 10^{-5}$ & $5 \times 10^{-6}$ & . \\
\hline $1.7 \times 10^{-2}$ & $2.4 \times 10^{-3}$ & . \\
\hline $2.4 \times 10^{-2}$ & $1.2 \times 10^{-2}$ & . \\
\hline $3.5 \times 10^{-4}$ & $1.4 \times 10^{-4}$ & . \\
\hline $7 \times 10^{-5}$ & $5 \times 10^{-5}$ & . \\
\hline $0.001 \%$ & $0.0005 \%$ & . \\
\hline $0.05 \%$ & $0.01 \%$ & . \\
\hline • & - & 2000 unit \\
\hline . & . & $1.8 \times 10^{-4}$ \\
\hline . & . & $1.1 \times 10^{-4}$ \\
\hline $1.4 \times 10^{-2}$ & $7 \cdot 2 \times 10^{-5}$ & . \\
\hline $1 \times 10^{-3}$ & $2.5 \times 10^{-4}$ & . \\
\hline $0.5 \%$ & $0.1 \%$ & . \\
\hline $0.5 \%$ & $0.1 \%$ & . \\
\hline • & · & $1 \times 10^{-3}$ \\
\hline • & $1 \times 10^{-4}$ & . \\
\hline
\end{tabular}




\section{DISCUSSION}

Since both electrolytes and non-electrolytes cause turbidity changes in bacterial suspensions, the optical effect seems to be essentially an osmotic phenomenon. The quantitative deviations from the osmotic law might be attributed to permeability factors. It appears likely that the o.E. is due to changes in the state of swelling of the bacterial cytoplasm determined by the tonicity of the suspending medium. Plasmolysis, however, seems not to be involved since the largest increase in turbidity occurs within the "physiological' range of the osmotic pressure (up to $0 \cdot 15 \mathrm{M}-\mathrm{NaCl}$ ).

The reason for the absence of the o.E. in Gram-positive bacteria is not clear. The findings of Brudny (1908) and of Eisenberg (1910), that Gram-positive species cannot be plasmolysed even by very high salt concentrations, suggest that these micro-organisms are more refractory to variations in osmotic pressure than the Gram-negative bacteria. However, it is also possible that in Gram-positive bacteria the osmotic phenomenon (changes in the water content of the cytoplasm) does not manifest itself by changes in light scattering.

The existence of the optical effect (o.E.) calls for more caution in using the turbidimetric procedure for measuring cell concentration in bacterial suspensions; the failure to consider the osmotic strength of the medium may lead to up to $100 \%$ deviations between individual estimations. On the other hand, since the o.E. seems to depend on the viability of the bacterial cell (some exceptions will be dealt with in the second part of this communication), it may be applied under carefully controlled conditions as a rapid and sensitive method for estimation of the number of viable cells.

\section{REFERENCES}

Brudny, V. (1908). Zbl. Bakt. (2. Abt.), 21, 62. Cited after Knaysi, G. (1951). Elements of Bacterial Cytology, p. 347. Ithaca, New York: Comstock Publishing Co. Inc.

Burke, V. (1922). Notes on the Gram stain with description of a new method. J. Bact. 7, 159.

Colländer, R. (1937). The permeability of plant protoplasts to non-electrolytes. Trans. Faraday Soc. 33, 985.

Danielli, J. F. (1952). The Permeability of Natural Membranes. Cambridge University Press.

Eisenberg, P. (1910). Zbl. Bakt. (1. Abt. Orig.), 56, 183; cited after Knaysi, G. (1951). Elements of Bacterial Cytology, p. 349. Ithaca, New York: Comstock Publishing Co. Inc.

Mager, J., Kindler, S. H. \& Grossowicz, N. (1954). Nutritional studies with Clostridium parabotulinum Type A. J. gen. Microbiol. 10, 130.

Mager, J., Traub, A. \& Grossowicz, N. (1954). Cultivation of Pasteurella tularensis in chemically defined media: effect of buffers and spermine. Nature, Lond. 174, 747 .

Winslow, C.-E. A. \& FALK, I. S. (1923). Studies on salt action. IX. The additive and antagonistic effects of sodium and calcium chlorides upon the validity of Bact. coli. J. Bact. 8, 237.

(Received 21 July 1955) 